Diabetologia 11, 77-82(1975)

(c) by Springer-Verlag 1975

\title{
Distribution of Blood and Serum Protein Group Characteristics in Patients with Diabetes
}

\author{
W. Scholz, R. Knußmann and H. Daweke \\ Arbeitsgruppe Humancytogenetik und klinische Genetik, Ruhr-Universität Bochum, Anthropologisches Institut, Universität \\ Hamburg, and Medizinische Klinik, Knappschaftskrankenhaus Bochum-Langendreer
}

Received: July 28, 1974, and in revised form: October 28, 1974

Summary. In a sample of 1.033 diabetic patients characteristics of 10 group specific systems (ABO, MNS, Rh, P, K and Fy blood groups and $\mathrm{Hp}, \mathrm{Gc}$ and $\mathrm{Gm}$ serum types) were tested in order to verify any association of hereditary group specific traits and diabetes. The patients were subgrouped for sex, seriousness of diabetes, age of manifestation and body type. The frequencies of the group specific traits were statistically compared with those of an appropriate control group using the $\chi^{2}$ test. Resulting from that investigation an increase of blood group 0 was found in diabetics below average in corpulence (basing upon the Rohrer index), and a confirmation was found for an already suspected association of diabetes and the $\mathrm{Gm}(\mathrm{a}+\mathrm{x}+)$ type.

Key words: Blood groups and disease, blood group association, selection in diabetes, diabetes type differentiation.
Since the positive identification of relations between blood group characteristics and certain diseases [1], the older assumption has been proven that the group characteristics have to be taken into consideration in selection processes. In respect to this view those diseases, which are relatively common in the general population, are of particular interest. A series of investigations concerning the relations between disease and blood group type are available for diabetes, but the uncertainities have not yet been definitively evaluated.

One of the first critical studies of association between diabetes and $\mathrm{ABO}$ characteristics was carried out in 1956 [10]. An increase of type A in diabetic patients was found, which was statistically significant and seemed independent of age of disease manifestation.

These findings could not be confirmed without objections by subsequent investigations. Either the relation was found only in part $[8,3]$, or the association was limited to certain subgroups of diabetic persons, as in the case of the late manifested form $[2,9]$ or as in diabetes among women only [11]. In an comprehensive survey it was found that the "advantage of the 0 group in comparison with the other groups is not extremely considerable but nonetheless statistically satisfactory" [16]. Diverse investigations of different diabetes types because are recommended of the suspected etiological differences.

\section{Material and Methods}

This prospective study is based entirely on investigations of 1.033 newly diagnosed diabetics. The investigated patients were in- and out-patients of the II. Internal Medicine Clinic of the University Düsseldorf in the years 1967 to 1969 and of the DiabeticClinic Hösel during 1969. In addition to clinical diagnosis and blood group typing a series of other variables was included, in order to obtain a meaningful differentiated sample. Accordingly the patients have been divided into groups as follows:

sex,

seriousness of illness, determined on the basis of clinical treatment: diet (D), diet and oral antidiabetic agents $(D+T)$, and diet and insulin treat$\operatorname{ment}(\mathrm{D}+\mathrm{I})$,

age of onset of diabetic symptoms, age at time of examination,

body type, determined by "corpulence" according to the Rohrer index based on height and weight (see ref. 7).

The serological tests extend to the erythrocyte antigen systems

ABO (with A subgrouping),

MNS,

Rhesus (C, c, D, E and e),

$\mathrm{P}$,

Kell (K) and

Duffy (Fy(a))

as well as to the serum protein types

Hp (haptoglobins),

Gc (group specific components of $\alpha_{2}$-globulin) and $\mathrm{Gm}$ ( $\gamma$-globulin polymorphism).

A random sample of approx. 2.350 adults from the same region at about the same time of investigation [13] was selected as a control group. 
All personal, clinical and serological data from the patients, were transfered to punch cards and the evaluation of frequencies was carried out with the help of a Siemens 2002 computer at the computer center of the University Düsseldorf. We used the $\chi^{2}$ test (see ref. 18, p. $509 \mathrm{f}$.) for determination of error probability of the hypothesis, that two comparable garded $P=0.05$ to 0.01 (possible true difference), $P=0.01$ to 0.0027 (very probable true difference), and $P<0.0027$ (certain true difference) as significance limits.

The results of the serological investigations and the statistical group comparisons are shown in the Table 1 through 4 according to the different group

Table 1. ABO-distribution in diabetic patients and control

\begin{tabular}{|c|c|c|c|c|c|c|c|c|}
\hline . & $\mathrm{n}$ & 0 & $A_{1}$ & $A_{2}$ & B & $A_{1} B$ & $\mathrm{~A}_{2} \mathrm{~B}$ & $P$ in $\%$ \\
\hline \multicolumn{9}{|l|}{ Control } \\
\hline male & 1351 & 40,0 & 34,4 & 9,4 & 11,4 & 3,2 & 1,6 & \\
\hline female & 998 & 41,0 & 35,0 & 8,6 & 9,8 & 3,9 & 1,7 & \\
\hline total & 2349 & 40,5 & 34,6 & 9,1 & 10,8 & 3,5 & 1,5 & \\
\hline \multicolumn{9}{|l|}{ Diabetics } \\
\hline total & 1032 & 39,3 & 36,2 & 9,6 & 11,4 & 2,8 & 0,6 & \\
\hline male & 441 & 39,0 & 35,1 & 10,7 & 11,6 & 2,9 & 0,7 & \\
\hline female & 591 & 39,6 & 37,1 & 8,8 & 11,3 & 2,7 & 0,5 & -95 \\
\hline \multicolumn{9}{|l|}{ Treatment } \\
\hline D & 91 & $38, \dot{5}$ & 41,8 & 6,6 & 11,0 & 2,2 & 0,0 & $>70-90$ \\
\hline $\mathrm{D}+\mathrm{T}$ & 429 & 39,6 & 35,7 & 9,8 & 11,7 & 2,6 & 0,72 & $\begin{array}{r}r-90 \\
-99 \\
\end{array}$ \\
\hline $\mathbf{D}+\mathbf{I}$ & 508 & 39,0 & 35,8 & 10,0 & 11,4 & 3,1 & $0,6=$ & $\therefore 70-90$ \\
\hline \multicolumn{9}{|c|}{ Manifestation } \\
\hline$<40$ & 311 & 42,8 & 33,4 & 9,0 & 10,3 & 3,9 & 0,6 & \\
\hline$>40$ & 721 & 37,9 & 37,4 & 9,8 & 11,9 & 2,4 & 0,6 & \\
\hline \multicolumn{9}{|l|}{ Age } \\
\hline$<25$ & 80 & 45,0 & 28,8 & 11,3 & 11,3 & 3,8 & 0,0 & $>70-90$ \\
\hline $25-50$ & 258 & 39,9 & 34,9 & 8,1 & 12,8 & 4,3 & 0,0 & $>20-30$ \\
\hline$>50$ & 694 & 38,5 & 37,6 & 9,9 & 11,0 & 2,2 & 0,9 & $\therefore 50-70$ \\
\hline \multicolumn{9}{|l|}{ Corpulence } \\
\hline below av. & 68 & 60,3 & 29,4 & 4,4 & 5,9 & 0,0 & $0,0 r$ & $>0,1-1,0$ \\
\hline average & 772 & 37,3 & 35,6 & 10,1 & 12,7 & 3,5 & $0,8<$ & $>10-20$ \\
\hline above av. & 188 & 40,4 & 41,0 & 9,0 & 3,5 & 1,1 & 0,0 & $=10-20$ \\
\hline
\end{tabular}

\footnotetext{
$\mathrm{n}=$ number of examined individuals; the given percentiles of group characteristics add in each row to total 100

$\mathrm{P}=$ probability of error in percent according to $\mathrm{X}^{2}$-test

D, T, I: see explanations in section "Material and Method"
}

Corpulence according to Rohrer-index

Rohrer index in

\begin{tabular}{|c|c|c|}
\hline males & females & \\
\hline$<\quad 1,2$ & $<\quad 1,2$ & : "below average" (under \\
\hline $1,2-1,8$ & $1,2-2,0$ & (normal weig \\
\hline$>1,8$ & $>2,0$ & : "above average" (over weight) \\
\hline
\end{tabular}

groups differ independent of chance in their frequency distribution. In addition numerous individual percent pairs were tested by the $t$ distribution test for a significant difference (see ref. 18, p. 194f.). The calculation of $\chi^{2}$ and $\mathrm{t}$ tests were performed with the included control group by a programmed portable calculator. As usual in statistic comparisons we re- systems showing significant differences. Details are given in the legends.

\section{Discussion and Results}

The following conclusions have been drawn from the comparison tests for the distributions of group 
characteristics in the whole group and the subgroups as given in the tables:

\section{Distribution of Blood Group Characteristics}

1. In the ABO distribution (Table 1) the apparent difference between control and total sample of diabetics shows the same deviation as found by most other authors: a slight increase of $\mathrm{A}$ with a respective decrease of 0 (see ref. 17). Nevertheless the difference in our material is not significant. were found in inter-group comparisons for both sexes and for degrees of seriousness of illness.

4. There is a slightly significant deviation in the distribution demonstrable in subgrouping patients according to corpulence (Table 1, below), which is primarily due to the 0 frequencies as proven by the single t test $(P<0.01)$.

Comparing these subgroups, the strongest deviation exists between the normal group and the "thin diabetics", who show an increase of 0 and a decrease of $A\left(A_{1}\right.$ as well as $\left.A_{2}\right)$. This subgroup is partially

Table 2. Rhesus-distribution in diabetic patients and control

\begin{tabular}{|c|c|c|c|c|c|c|c|c|}
\hline & $\mathrm{n}$ & $R_{1} R_{1}$ & $R_{1} r$ & $R_{1} R_{2}$ & $\mathrm{R}_{2} \mathrm{r}$ & $\mathrm{R}_{2} \mathrm{R}_{2}$ & $\mathrm{rT}$ & others $\mathrm{P}$ in $\%$ \\
\hline \multicolumn{9}{|l|}{ Control } \\
\hline male & 1350 & 17,7 & 33,2 & 14,0 & 11,6 & 1,9 & 14,6 & 7,0 \\
\hline female & 999 & 18,2 & 36,5 & 11,7 & 10,1 & 2,3 & 15,7 & 6,0 \\
\hline total & 2349 & 18,0 & 34,5 & 13,1 & 10,9 & 2,1 & 14,8 & 6,6 \\
\hline \multicolumn{9}{|l|}{ Diabetics } \\
\hline total & 1033 & 20,1 & 36,1 & 12,1 & 11,1 & 1,7 & 14,9 & 3,9 \\
\hline male & 442 & 21,3 & 36,0 & 12,4 & 9,5 & 2,3 & 15,6 & $2,9-$ \\
\hline female & 591 & 19,3 & 36,2 & 11,8 & 12,4 & 1,4 & 14,4 & $4,6-$ \\
\hline \multicolumn{9}{|l|}{ Treatment } \\
\hline D & 91 & 15,4 & 41,8 & 8,8 & 11,0 & 0,0 & 18,7 & 4,4 i \\
\hline $\mathbf{D}+\mathbf{T}$ & 429 & 19,4 & 34,5 & 13,8 & 10,5 & 2,6 & 14,2 & $20-30$ \\
\hline $\mathbf{D}+\mathbf{I}$ & 509 & 21,4 & 36,5 & 11,4 & 11,6 & 1,4 & 14,9 & $50-70$ \\
\hline \multicolumn{9}{|l|}{$\begin{array}{l}\text { Mani- } \\
\text { festation }\end{array}$} \\
\hline$<40$ & 311 & 18,7 & 34,7 & 12,9 & 11,3 & 1,9 & 17,0 & 3,5 \\
\hline$>40$ & 722 & 20,8 & 36,7 & 11,8 & 11,1 & 1,7 & 14,0 & 4,0 \\
\hline \multicolumn{9}{|l|}{ Age } \\
\hline$<25$ & 80 & 15,0 & 41,3 & 16,3 & 11,3 & 2,5 & 10,0 & $50-70$ \\
\hline $25-50$ & 258 & 19,0 & 34,5 & 12,4 & 11,6 & 1,6 & 17,4 & $90-95$ \\
\hline$>50$ & 695 & 21,2 & 36,1 & 11,5 & 10,9 & 1,7 & 14,5 & $\begin{array}{l}50-93 \\
50-70\end{array}$ \\
\hline \multicolumn{9}{|l|}{ Corpulence } \\
\hline below av. & 68 & 16,2 & 42,6 & 16,2 & 7,4 & 1,5 & 13,2 & $70-90$ \\
\hline average & 773 & 19,9 & 34,5 & 12,6 & 11,8 & 1,9 & 15,9 & $>10-20$ \\
\hline above av. & 188 & 22,3 & 39,4 & 9,0 & 10,1 & 1,1 & 11,7 & $50-70$ \\
\hline
\end{tabular}

For explanation of signs see Table 1

2. As in former investigations $[2,9]$ the blood type 0 decreases in patients whose diabetes manifested itself at over 40 years of age, with type A and B increasing correspondingly. Although this tendency has been shown in our material (Table 1), the results were not statistically significant. No support was found for the contradictory results with an excess of type 0 in young diabetics [14].

3. No differences in the ABO distribution (Table 1) overlapping those of young diabetics and severely affected (without significance however, in these tests).

It seems that those diabetics of average weight and those over-weight conform with the ABO distribution in the controls, and that only the thin, i.e. the small group of under-weight patients, display a higher 0 frequency. The tendency of that deviation is conspicious in as far as an increase in the frequency of $A$ and not $O$ is found in the total material and in 
other investigations, when a classification according to corpulence of the diabetics was not carried out.

5. The Rh-factors were tested for distribution by use of 5 antisera anti-D, anti-C, anti-c, anti-E, anti-e. The obtained $\mathrm{Rh}$-subtypes (Table 2) lead thus to a corresponding division of the material. A deviation exists in the present material in the type distribution between control and the total diabetic group. The single tests demonstrate that the portion of $\mathrm{Rh}$ negative persons is practically the same in both groups, and the difference is based on an increase valid for the $\mathrm{MN}$ and $\mathrm{S}$ distributions, whereby only the type $M$ (homozygous MM) was found to be $6 \%$ more frequent in diabetics with onset before 40 in opposition to those with manifestation after $40(P=$ $2-5 \%)$. The lack of association in these systems agree with those of a smaller sample investigated [3].

\section{Distribution of Serum Protein Characteristics}

6. In the $\mathrm{Hp}$ distribution (Table 3 ) a deviation was found in the sense that $\mathrm{Hp} 1-1$ and $\mathrm{Hp} 2-2$ were

Table 3. Hp- and Ge serum protein type distribution in diabetics and control

\begin{tabular}{|c|c|c|c|c|c|c|c|c|c|}
\hline & $\mathbf{n}$ & $1-1$ & $2-1$ & $2-2$ & Ahapt. & $1-1$ & $2-1$ & $2-2$ & $\mathbf{P}$ in $\%$ \\
\hline \multicolumn{10}{|l|}{ Control } \\
\hline male & 1348 & 14,3 & 48,7 & 37,0 & & 53,0 & 39,1 & 7,9 & \\
\hline female & 997 & 14,4 & 50,8 & 34,8 & & 53,9 & 38,0 & 8,0 & \\
\hline total & 2345 & 14,3 & 49,6 & 36,1 & & 53,5 & 38,6 & 7,9 & \\
\hline \multicolumn{10}{|l|}{ Diabetics } \\
\hline total & 1029 & 15,5 & 46,8 & 37,1 & 0,6 & 51,9 & 39,9 & 8,2 & \\
\hline male & 439 & 16,2 & 44,4 & 38,7 & $0,7 \longrightarrow 50-70$ & 53,7 & 38,1 & $8,2-$ & $=50-70$ \\
\hline female & 590 & 14,9 & 48,6 & 35,9 & $0,5 \longrightarrow 50-70$ & 50,5 & 41,2 & $8,3-$ & $-50-70$ \\
\hline \multicolumn{10}{|l|}{ Treatment } \\
\hline $\mathrm{D}$ & 90 & 18,9 & 42,2 & 38,9 & $>70-90$ & 46,7 & 45,6 & 7,8 & $-70-90$ \\
\hline $\mathrm{D}+\mathrm{T}$ & 429 & 17,5 & 47,1 & 35,0 & $0,5 \stackrel{\square}{\perp} 20-30$ & 50,6 & 42,7 & $6,8 \sum$ & $-5-10$ \\
\hline $\mathrm{D}+\mathrm{I}$ & 506 & 13,2 & 47,2 & 38,7 & $0,8 \sim->30-50$ & 53,9 & 36,4 & $9,6<$ & $=20-30$ \\
\hline \multicolumn{10}{|c|}{ Manifestation } \\
\hline$<40$ & 309 & 12,3 & 43,0 & 44,0 & $>1-2$ & 53,7 & 37,6 & $8,7-$ & $.50-70$ \\
\hline$>40$ & 720 & 16,8 & 48,5 & 34,2 & $0,6-$ & 51,1 & 40,8 & 8,1 & $20-10$ \\
\hline \multicolumn{10}{|l|}{ Age } \\
\hline$<25$ & 79 & 12,7 & 44,3 & 43,0 & $>70-90$ & 51,3 & 41,3 & $7,5 \div$ & $-70-90$ \\
\hline $25-50$ & 257 & 12,8 & 42,4 & 44,0 & $0,8 \leftrightharpoons 2,5-5$ & 53,5 & 38,4 & $8,1 \geq$ & $-70-90$ \\
\hline$>50$ & 693 & 16,7 & 48,8 & 33,9 & $0,6 \div-530-50$ & 51,4 & 40,3 & $8,4=$ & $=95-97,5$ \\
\hline \multicolumn{10}{|l|}{ Corpulence } \\
\hline below av. & 68 & 22,1 & 39,7 & 38,2 & $=30-50$ & 54,4 & 35,3 & $10,3 \leftarrow$ & $-50-70$ \\
\hline average & 769 & 15,7 & 45,8 & 37,8 & $0,7 \stackrel{\searrow}{\longleftarrow} 20-30$ & 53,0 & 39,8 & 7,12 & $-2,5-5$ \\
\hline above av. & 188 & 11,7 & 53,2 & 34,6 & $0,5-\leq=10-20$ & 46,8 & 41,0 & $12,2 \leftarrow$ & $\leq 50-70$ \\
\hline
\end{tabular}

For explanation of signs see Table 1

of the types $R_{1} R_{1}$ and $R_{1} r$ in diabetics. The significance, however, remains weak with $P=5 \%$, so that reservation in formulation of conclusions is necessary, particularly since other authors have obtained divergent results, finding an increase of $\mathbf{R}_{2}$ complex and a decrease of the types $\mathrm{R}_{1} \mathrm{R}_{\mathbf{1}}(P<1 \%, \mathrm{n}=180)$ in diabetics [3].

In the same manner the material was analysed for the blood group systems P, Kell, and Duffy. At no point was there a definite deviation in comparison with the control or with other groups. The same is somewhat more and the heterozygous type $\mathrm{Hp} \mathrm{2-1}$ somewhat less frequent than in the control but significance was not obtained. Six cases of ahaptoglobinaemia among diabetic patients were omitted from the statistical evaluation, since ahaptoglobinaemia frequencies were not given in the control. Overall these result did not show the same tendencies as those of other investigators, who observed a reduction of the allele $\mathrm{Hp}^{1}$ in diabetics [6] or showed a corresponding increase of type $\mathrm{Hp} \mathrm{1-1}$ and a decrease of type $\mathrm{Hp}$ $2-2$ in diabetics [3]. 
7. In the Gc system (Table 3) there was no significant difference in the comparison: control/total patient sample. This shows agreement of our larger sample with that of other authors $[4,5,3]$. In the break-down of the patient sample a frequency of $\mathrm{Gc}$ $1-1$ of approximately. $6 \%$ less was found in overweight patients and corresponding higher frequencies of the other types $(2,5 \%<P<5 \%)$.

8. A significant difference between the control and the complete diabetic group in the $\mathrm{Gm}$ distribution

Table 4. Gm serum protein type distribution in diabetics and control

\begin{tabular}{|c|c|c|c|c|c|}
\hline & $\mathrm{n}$ & $\begin{array}{l}\mathrm{Gm} \\
(\mathrm{a}-\mathrm{x}-)\end{array}$ & $\begin{array}{l}G m \\
(a+x-)\end{array}$ & $\begin{array}{l}\text { Gm } \\
(a+x+)\end{array}$ & $\mathrm{P}$ in $\%$ \\
\hline \multicolumn{6}{|l|}{ Control } \\
\hline male & 1351 & 48,3 & 35,1 & 16,6 & \\
\hline female & 1000 & 50,3 & 34,2 & 15,5 & \\
\hline total & 2351 & 49,2 & 34,6 & 16,2 & \\
\hline \multicolumn{6}{|l|}{ Diabetics } \\
\hline total & 1028 & 48,5 & 31,5 & 19,9 & \\
\hline male & 439 & 48,3 & 29,8 & $21,9-$ & $30-50$ \\
\hline female & 589 & 48,7 & 32,8 & 18,5 & $0-50$ \\
\hline \multicolumn{6}{|l|}{ Treatment } \\
\hline $\mathrm{D}$ & 89 & 46,1 & 34,8 & 19,1 & $50-70$ \\
\hline$D+T$ & 429 & 48,5 & 33,3 & 18,2 & $-20-30$ \\
\hline $\mathrm{D}+\mathrm{I}$ & 506 & 49,0 & 29,2 & 21,7 & $50-70$ \\
\hline \multicolumn{6}{|c|}{ Manifestation } \\
\hline$<40$ & 310 & 48,1 & 29,4 & 22,6 & 0 \\
\hline$>40$ & 718 & 48,7 & 32,5 & 18,8 & \\
\hline \multicolumn{6}{|l|}{ Age } \\
\hline$<25$ & 79 & 41,8 & 34,2 & 24,1 & $30-50$ \\
\hline $25-50$ & 258 & 50,8 & 29,1 & 20,2 & $50-70$ \\
\hline$>50$ & 691 & 48,5 & 32,1 & 19,4 & $30-50$ \\
\hline \multicolumn{6}{|l|}{ Corpulence } \\
\hline below av. & 68 & 42,6 & 38,2 & $19,1-$ & $-30-50$ \\
\hline average & 769 & 48,8 & 31,1 & 20,1 & $-70-90$ \\
\hline above av. & 187 & 49,7 & 30,5 & 19,8 & $-30-50$ \\
\hline
\end{tabular}

For explanation of signs see Table 1

(Table 4) exists with an error probability of only 1 to $2 \%$. The Gm $(\mathrm{a}+\mathrm{x}+)$ type was more frequent, the type $\mathrm{Gm}(\mathrm{a}+\mathrm{x}-)$ less frequent among patients. This deviation was even more prevalent in males, although the difference between the sexes was not significant. Comparable results are only given in one other investigation [3]. There was also a statistically signifcant increase of $\mathrm{Gm}(\mathrm{a}+\mathrm{x}+)$ and decrease of $\mathrm{Gm}$ $(\mathrm{a}+\mathrm{x}-)$ type found in diabetic patients. This investigation provides therefore a validation of these results.
Finally it should be remembered that when a large number of significance tests are performed, some excess by chance of the conventionally determined limit of error probability will occur. A prudent evaluation of the findings is therefore necessary. Meaningful are results by several authors investigating different samples which display the same association; as is particularly seen in the Gm system. It is regarded premature, however, to form an opinion as to whether or not that association between $\mathrm{Gm}$ characteristics and diabetes might be an expression of an immunological process involving the $\gamma$-globulins.

\section{References}

1. Aird, I., Bentall, H. H., Roberts, J. A. F.: A relationship between cancer of stomach and the ABO groups. Brit. med. J. 1953 I, 799

2. Andersen, J., Lauritzen, E.: Blood groups and diabetes mellitus. Diabetes 9, 20-24 (1960)

3. Berg, K., Aarseth, S., Lundevall, J., Reinskou, T.: Blood groups and genetic serum types in diabetes mellitus. Diabetologia 3, 30-34 (1967)

4. Cleve, H.: Die Verteilung der Gc-Typen und Gc-Allele bei Kranken mit Diabetes mellitus. Hum. Genet. 2, 355362 (1966)

5. Jörgensen, G., Hopfer, H.: Die Verteilung der Gc-Phänotypen und Gc-Allele bei einigen Krankheiten (Diabetes mellitus, Leberparenchymschaden, Psoriasis vulgaris). Hum. Genet. 3, 273-276 (1967)

6. Jörgensen, G., Hopfer, H.: Die Verteilung der Haptoglobinphänotypen und Haptoglobinallele bei einigen Krankheiten (Diabetes mellitus, Leberparenchymschaden, Psoriasis vulgaris). Hum. Genet. 3, 277-281 (1967)

7. Knußmann, R., Toeller, M., Holler, H. D.: Zur Beurteilung des Körpergewichts. Med. Welt (Berl.) 23, 529535 (1972)

8. Macafee, A. L.: Blood groups and diabetes mellitus. J. clin. Path. 17, 39-41 (1964)

9. Mai, K.: Methodischer Beitrag zur Frage der Beziehungen zwischen Blutgruppen und Krankheiten am Beispiel des Diabetes mellitus. Habil.-Schrift, Hamburg 1963

10. McConnell, R. B., Pyke, D. A., Roberts, J. A. F.: Blood groups in diabetes mellitus. Brit med. J. 1956 I, 772-776

11. Revai, S., Konig, E.: Vorkommen der Blutgruppen ABO bei an Diabetes mellitus leidenden Kranken. Z. Arztl. Fortbildg. (Jena) 62, 1087-1088 (1968)

12. Sauer, H., Mai, K., Otto, H.: Untersuchungen zur Blutgruppenverteilung beim Diabetes mellitus. Klin. Wschr. 41, 1052-1054 (1963)

13. Scholz, W., Heinz-Grabensee, J.: Zur Häufigkeitsverteilung von Blutgruppenmerkmalen im Einzugsbereich Düsseldorf. Rhein. Arztebl. 20, 721 (1973)

14. Serra, A., Klinger, R., Gualandri, V.: The relation of diabetes mellitus to the blood group phenotypes $\mathrm{O}, \mathrm{A}, \mathrm{B}$ and AB. Panminerva med. 6, 160 (1964)

15. Simpson, N. E., Gunson, H. H., Smithies, O.: Frequencies of blood groups, serum haptoglobins and levels of slow alpha ${ }^{2}$-globulin in diabetics and their relatives. Diabetes 11, 329-333 (1962)

16. Vogel, F., Krüger, J.: Statistische Beziehungen zwischen 
den ABO-Blutgruppen und Krankheiten mit Ausnahme der Infektionskrankheiten. Blut 16, 351-376 (1968)

17. Vogel, F., Helmbold, W.: Blutgruppen-Populationsgenetik und Statistik. In: Becker, P. E.: Humangenetik, Handbuch Bd. I/4, 129. Stuttgart: Thieme 1972

18. Weber, E.: Grundriß der biologischen Statistik. Stuttgart: G. Fischer 1972
Prof. Dr. W. Scholz

Ruhr-Univ. Bochum

463 Bochum

Postfach 2148

Federal Republic of Germany 